\title{
Effect of Soybean, Virgin Coconut and Moringa oleifera Seed Oils on the Propylthiouracil Induced Hypothyroidism in Rats
}

\author{
Shaimaa H. Negm
}

\begin{abstract}
This study investigated the possible effect of soybean, virgin coconut and Moringa oleifera seed oils for 8 weeks on Propylthiouracil (PTU) induced hypothyroidism in rats. Thirty five male albino rats were divided into two main groups; Group (I) (7 rats) was fed only basal diet and served as a negative control group. Group (II) (28 rat) were injected with (10 $\mathrm{mg} / \mathrm{kg} /$ day PTU) for 15 day to cause hypothyroidism, then divided into 4 subgroups: namely control positive group based on basal diet, and $2^{\text {nd }}$, $3^{\text {rd }}$ and $4^{\text {th }}$ subgroup were treated orally with dose of $5 \mathrm{ml} / \mathrm{kg} \mathrm{BW}$ oils of Soybean (SO), Virgin coconut (VCO) and M.oleifera seeds (MOO), respectively beside basal diet. The results showed that PTU exposed rats showed significant decrease $(P \leq 0.05)$ in serum FT3, FT4 levels and significant increase $(\mathrm{P} \leq \mathbf{0 . 0 5})$ in serum TSH levels. The orall treatement with SO, VCO and MOO was significantly increased FT4 and FT3, while decreased the level of TSH comparing with the positive control group. It was also reduced level of malondialdehyde (MDA) level, significantly, increased activity of liver antioxidant enzymes-superoxide dismutase (SOD) and improved liver functions and lipid profile compared with the positive control group. So, it could be concluded that oils of soybean, virgin coconut and $M$. oleifera seed oils improve the role of thyroid by raising thyroid hormones and reducing oxidative stress in patients with hypothyroidism.
\end{abstract}

Keywords: Hypothyroidism, Moringa oleifera seeds, Propylthiouracil, soybean oil, virgin coconut oil, thyroid stimulating hormone.

\section{INTRODUCTION}

Around 42 million people are estimated to suffer from thyroid disease (Bagcchi, 2014). Hypothyroidism is the most common thyroid condition. It is linked to various metabolic abnormalities, affecting one in ten adults. Hypothyroidism can occur due to iodine intake deficiency, lesions of the thyroid gland, autoimmune disorders, and pituitary gland impaired activity (Ott et al., 2011). The definition of hypothyroidism is lower serum FT3, FT4, and higher TSH (Dons and Wians, 2009). Thyroxine (T4) and tri-iodothyronine (T3) are necessary for the physiological functions of almost all body tissues (Sharma et al., 2018). They regulate reproductive functions, heart pulses, body thermogenesis, gastrointestinal motility and emotional stability. In addition, they control metabolism of proteins, lipid and carbohydrate (Nair et al., 2015).

Propylthiouracil (PTU) is an antithyroid thioamide drug. It has been used for more than half a century in the treatment of hyperthyroidism. This establishes a status of hypothyroidism (Bertram, 2012). Disorder of thyroid function may produce various subclinical or clinical manifestations (Chaker et al., 2017), such as weight change, sweating, exhaustion, lethargy, cold resistance, voice change, an increase in metabolism of cholesterol, decrease in metabolic rate. Sometimes, there may be swelling of the front part of the neck due to goiter diseases (Louzada and Carvalho, 2018). Hypothyroidism is related to oxidative stress due to excessive free radical growth (Chakrabarti et al., 2016).

As an approach to modulating defects and oxidative stress-induced pathologies associated with thyroid disorders, the growing trend towards prevention supports the efficacy of natural products and their derivatives. It resulted in increased interest in using the beneficial ability of the antioxidant properties of natural products to quench or break free radical chain. A growing collection of evidence shows that soybean, virgin coconut and moringa oleifera seed oils possesses antioxidant and pharmacological activities (RetanaMarquez et al., 2012 and Famurewa et al., 2019).

The most important dietary source of isoflavones is soybean [Glycine $\max (\mathrm{L}$.$) ], an essential class of$ phytoestrogen (Cederroth et al., 2012). Soybean oil (SO), derived from soybean, is the world's most widely commercial edible oil (Hayes and Khosla, 2007). Soybean oil contains about $60 \%$ of polyunsaturated fatty acids (PUFAs), $24 \%$ of monounsaturated fatty acids (MUFA) and $16 \%$ of saturated fatty acids (SFAs) (Warner, 2005). Positive results between soy isoflavone intake and lower incidences of diseases have promoted the popularity and safe value of soybean (Shu et al., 2009), due to it's many estrogenic and antioxidant activites (Retana-Marquez et al., 2012). Also, crude soybean oil has natural antioxidants inhibit lipid peroxidation (Zainuddin et al., 2015).

Virgin coconut oil (VCO) or coconut butter, is extracted from coconut. It has a long shelf life without chemical refining (Jaarin et al., 2014). It has a long shelf

DOI: 10.21608/ASEJAIQJSAE.2019.66050

${ }^{1}$ Home Economic Dept., Specific Education Faculty, Port Said University, Egypt.

Received November 17, 2019, Accepted December 24, 2019 
life without chemical refining. It is used in the baking and manufacturing of pharmaceutical products (Krishna et al., 2010). It is consisted mainly of a combination of short- and medium-chain (SFAs) (92\%) in addition to low level of unsaturated fatty acids (8\%) (Che Man and Marina, 2006).

Studies on the biological effects of VCO showed its ability to improve the antioxidant defense system, by inhibiting free radicals. This helps in reducing lipid peroxidation (Iranloye, 2013), keeping high-density lipoprotein (HDL), total cholesterol levels and decreasing low-density lipoprotein (LDL) levels in serum and tissues of rats (Nevin and Rajamohan, 2006), and body fat accumulntion (Takeuchi et al., 2008 and Iranloye et al., 2013). The pharmacological effects of VCO are due to their phenolic content which increases from its antioxidant and cholinergic activites and reduces oxidative stress (Rahim et al., 2017).

Moringa oleifera seed oil (MOO) is a light yellow oil with an acceptable nutty flavour. The oil consists of $82 \%$ unsaturated fatty acids, $70 \%$ of which is oleic acid. It has relatively more oleic acid than olive oil (Rahman et al., 2014). It is a good source of flavonoids which have health promoting properties (Kou et al., 2018). Its therapeutic effectiveness against thyroid disorders was observed (Lin et al., 2018). It has antioxidant, hepatoprotective, nephrotoxicity and testicular protective in rats (Olatosin et al., 2013; Abarikwu et al., 2017and Gupta et al., 2018). The present work was aimed to investigate the changes of thyroid function induced by PTU and effect of soybean, virgin coconut and moringa oleifera seed crude oils on hypothyroidism.

\section{MATERIALS AND METHODS}

\section{Plant materials:}

- Soybean, coconut and Moringa oleifera seeds were procured from the local food company in Egypt. Plant materials were identified and authenticated by a plant taxonomist, Faculty of Agriculture, Ain Shams University.

- Chemicals: Casein, vitamins, minerals, cellulose, choline chloride were bought from El- Gomhoria Company, Cairo, Egypt. Propylthiouracil was obtained from the local distributer of SigmaAldrich Chemical Co. USA. Kits for biochemical analysis were purchased from Biodiagnostic Company for Pharmaceutical and chemicals, Dokki, Egypt.

- Animals: Thirty-five healthy male albino rats (Sprague-Dawley strain) were bought from the Helwan Experimental Animals Station at the age of eight weeks $(185 \pm 20 \mathrm{~g})$.

\section{Methods:}

- Extraction of soybean oil: Soybean seeds were crushed to extract the oil using n-hexane as a solvent. The extracted oil was next purified by distillation to remove any hexane from oil according to the method of Wu et al. (2011).

- Extraction of virgin coconut oil: The wet coconuts are subjected to pressing to extract the oil out along with coconut milk. This is processed afterwards without employing heat, chemicals, refining according to the method of Krishna et al. (2010).

- Extraction of M. oleifera oil: Cold press method was used to obtain MOO from M.oleifera seeds without chemical treatment according to the method of Abarikwu et al. (2017).

Induction of Hypothyroidism: According to Sener et al. (2006), hypothyroidism was caused by intraperitoneal injection for 15 days once daily in rats using propylthiouracil, $10 \mathrm{mg}$ PTU / $\mathrm{kg} \mathrm{BW} /$ day. Blood was obtained by capillary tube from the rats ' eyes and the serum was isolated and tested to equate the T3, T4 and TSH levels with the negative control rats.

\section{Experimental animal design:}

The basal diet was formulated according to Reeves et al. (1993). Thirty five male albino rats were randomly divided into two main groups after the acclimatization time, (7) day. Group (I) (7 rat) was fed only with the basal diet and served as a negative control group. Group (II) (28 rat) were injected with (10 $\mathrm{mg} / \mathrm{kg} \mathrm{/} \mathrm{day} \mathrm{PTU)} \mathrm{for} 15$ day to cause hypothyroidism, then divided into 4 subgroups: namely the control positive group based only on basal diet, and $2^{\text {nd }}, 3^{\text {rd }}$ and $4^{\text {th }}$ subgroup were treated orally with a dose of $5 \mathrm{ml} / \mathrm{kg} \mathrm{BW}$ of $\mathrm{SO}, \mathrm{VCO}$ and $\mathrm{MOO}$, respectively beside basal diet. The dose of oils were chosen according to Famurewa et al, (2019). After 8 weeks, fasted rats were anesthetized with diethyl ether and sacrificed. The blood samples were obtained from each rat and centrifuged at $3500 \mathrm{rpm}$ for $20 \mathrm{~min}$.

Preparation of fatty acid methyl esters (FAMEs) and total tocopherols of SO,VCO and MOO: Fatty acid (FA) composition of the oils and fats were determined as their corresponding methyl esters (FAMEs) derived by transesterification or esterification from fats, oils, and fatty acids by capillary gas chromatography (GLC). Preparation of FAMEs was carried out according to ISO 12966 (2015) method. While HPLC was used to determine vitamin E according to AOAC (2005).

Determination of total phenolic content: The total phenolic content of the SO, VCO and MOO was determined by Folin-Ciocalteu colorimetric method (Zilic et al., 2012) and expressed as mg of gallic acid 
equivalent (GAE) per $100 \mathrm{~g}$ of oil.

Biochemical Analysis: Free triiodothyronine (FT3), free thyroxin (FT4) and TSH hormones were estimated via ELISA method using special kits (Shamsian et al., 2016). Oxidative stress markers: Superoxide Dismutase (SOD) and malondialdehyde (MDA) were determined according to Kakkar et al. (1984) \& Draper and Hadly (1990) methods, respectively. Serum aspartate aminotransferase (AST) and alanine aminotransferase (ALT) were measured according to Bergmeyer et al. (1978), while alkaline phosphatase (ALP) was determined according to Belfield and Goldberg (1971). Serum was analyzed for the following biochemical parameter: total cholesterol (TC) by the method of Fossati and Praneipe (1982), HDL-cholesterol by Albers et al. (1983), triglyceride (TG) by Jacobs and Vander (1960). While low density lipoprotein cholesterol (LDL-C) and very low density lipoprotein cholesterol (VLDL-C) were calculated according to the equation of Fruchart (1982). Low density lipoprotein cholesterol can be calculated as follows: $\mathrm{LDL}-\mathrm{C}=$ Total cholesterol - HDL-C -VLDL-C.

Statistical analysis: The results were expressed as mean \pm sandard Error (SE) and were analyzed statistically using one-way analysis of variance ANOVA. The results were considered signifcant at $\mathrm{P} \leq$ 0.05 . Calculations were made on SPSS software version 20 (SPSS Inc., Chicago, Illinois, USA) (Emsley et al., 2010).

\section{RESULTS AND DISCUSSION}

Natural oils such as SO, VCO and MOO are evolving as functional foods due to their healthpromoting pharmacological activities reported in published literature (Abarikwu et al., 2017؛ Famurewa et al., 2017and Ogedengbe et al., 2018). The current study was carried out to investigate the possible role of soybean, virgin coconut and moringa oleifera seed oils on thyroid hormones level, liver function, lipid profile and biological parameters in experimentally induced hypothyroidism of adult male albino rats.

The fatty acid profile of soybean, virgin coconut and $m$. oleifera seed oils are shown in Table (1). SO is rich in polyunsaturated fatty acids, it contains about $58.5 \%$ of (PUFAs), 26.5\% of (MUFA) and $14.5 \%$ of (SFAs), respectively, while VCO consisted mainly of a combination of short-and medium-chain (SFAs) $90.5 \%$ in addition to low level of unsaturated fatty acids $9.3 \%$. MOO is rich in monounsaturated fatty acids, it contains about $77.5 \%$ of (MUFA), its low in polyunsaturated fatty acids $1.5 \%$ of (PUFAs) and $20.6 \%$ of (SFAs).The obtained results are in agreement with Deol et al. (2015) who reported that soybean oil is rich in polyunsaturated fatty acids (PUFAs), it contains about $28.83 \%$ of (PUFAs), $11.8 \%$ of (MUFA) and 59.3\% of (SFAs).

Burnett et al. (2011) reported that, coconut oil is very commonly used as a tropical edible oil in many Asian cultures and is composed of almost 90- 95\% saturated fatty acids. Furthermore, Feranil et al. (2011) mentioned that coconut oil primarily comprises of lauric acid $(47.5 \%)$, a low molecular weight saturated fatty acid known to be a better alternative to other saturated fatty acids. Coconut oil is a saturated fat that is mainly composed of high proportion of medium-chain fatty acids (MCFA), lauric acid (source of vitamin E), and polyphenols with antioxidant activity (Nevin and Rajamohan, 2008 and Rabeh 2017).

Ogunsina et al. (2014) reported that cold pressed extracted moringa seed oils (CPMSO) had 79.5 of monounsaturated oleic acid and 80.7 of unsaturated fatty acids respectively. Leone et al. (2016) showed that $M$. oleifera seed oil falls in the category of high-oleic oils and contains a high monounsaturated to saturated fatty acids ratio (MUFA/SFA). However, the oil is a source of some minor compounds (phytosterols and tocopherols) (Saa et al., 2019).

The effect of soybean, virgin coconut and M.oleifera seed oils supplementation on serum TSH, FT3 and FT4 levels of rats induced with hypothyroidism are tabulated in Table (2). Rats exposed to PTU (exhibited hypothyroidism) showed a significant decrease $(\mathrm{P} \leq 0.05)$ in serum FT3, FT4 and higher increase in TSH concentrations compared to the negative control group.

Table 1. Fatty acid profile, vitamin $\mathrm{E}$ and total phenolics in soybean, virgin coconut and $M$. oleifera seed oils

\begin{tabular}{lcccc}
\hline & Component & $\begin{array}{c}\text { Soybean } \\
\text { oil }\end{array}$ & $\begin{array}{c}\text { virgin } \\
\text { coconut oil }\end{array}$ & $\begin{array}{c}\text { Moringa oleifera } \\
\text { seed oil }\end{array}$ \\
\hline Saturated fatty acid (SFA) & $(\%)$ & 14.5 & 90.5 & 20.6 \\
Unsaturated fatty acid: & Mono-unsaturated fatty acid (MUFA) & 26.5 & 8.8 & 77.5 \\
& Poly-unsaturated fatty acid (PUFA) & 58.5 & 0.5 & 1.5 \\
Tocopherols (mg/100 g) & 1.03 & 2.53 & 3.78 \\
Total phenolics (mg GAE/100g)* & 34.46 & 61.22 & 63.18 \\
\hline
\end{tabular}

* GAE: Gallic acid equivalent 
The supplementation with $\mathrm{SO}, \mathrm{VCO}$ and $\mathrm{MOO}$ caused significant $(\mathrm{P} \leq 0.05)$ increased in concentration of FT3, FT4 and a significant $(\mathrm{P} \leq 0.05)$ decrease in the $\mathrm{TSH}$, compared to the positive control group. No significant differences were noted in TSH level between the treated rats with VCO and MOO. The best thyroid functions were observed in rats fed on MOO compared to the other treated groups.

The results of Rabeh and El-Ghandour (2016) and Rabeh (2017) indicated that thyroid hormones were dramatically reduced by PTU. Bhanja and Chainy (2010) reported that hypothyroidism causes oxidative stress in rats. This leads to tissue damage and apoptosis.Fumarola et al. (2010) stated that PTU inhibits iodine oxidation and monodotyrosine ionization. It is also prevented the coupling stage and inhibited the peripheral conversion of (T4) to (T3).So, it suppresses the synthesis of thyroid hormones by blocking the activity of thyroid peroxidase (Sue et al., 2012).

Dietary fatty acids have marked influence on functioning of thyroid gland (Gupta et al., 2009). Some authors suggest that isoflavones have a moderate or no effect on the role of thyroid (Dillingham et al., 2007). Meanwhile others showed that isoflavones suppress the function of thyroid (Sathyapalan et al., 2011). Modaresi et al. (2014) reported that feed 30\% and/or 50\% soybean meal may result in an increase in TSH release. Bitto et al. (2010) concluded that postmenopausal women isoflavone intake for three years had no effect on thyroid functions. Soybean oil consumption by pregnant women up to three times a week has been shown to be safe without any effect on thyroid or thyroid autoimmune functions (Li et al. 2011). Sarathi et al. (2016) found that short-term soy food consumption did not change the functions of the maternal and neonatal thyroid. Otun et al. (2019) mentioned that soybean supplementation has no effect on thyroid hormones and may increase levels of TSH.

Gupta et al. (2009) found that coconut oil-fed rabbits had a significant reduction in TSH levels. This implies that saturated fats decrease serum TSH levels (as seen in Table 1). Rabeh (2017) found that, virgin coconut oil, curcumin, Vit.D or their mixture increased the level of thyroid hormones and lowered the level of TSH. Such effects may be due to high content in VCO of polyphenolic and other antioxidants. Takeuchi et al. (2008) and Rabeh (2017) found that coconut oil enhances thyroid functions.Tabassum et al. (2013) and Wazida et al. (2013) observed that ethanol extract of leaves moringa led to a significant increase in the level of T3 and T4 hormones and a significant decrease in TSH level. Also, Mohamed et al. (2019) found that oral administration of Moringa leaves extract to hyperthyroid rats can attenuate the reduction of plasma TSH.

Table (3) illustrates the impact of supplementing soybean, virgin coconut and M.oleifera seed oils on the levels of liver functions in rats suffer from hypothyroidism. The results showed that hypothyroidism caused significantly increase $(\mathrm{P} \leq 0.05)$ activity of ALT, AST and ALP in rats of the control positive group compared to the negative control group. This may be due to the disruption occurred in liver functions. Also the results showed that, feeding rats suffering from hypothyroidism with SO, VCO and MOO led to a significant decrease $(\mathrm{P} \leq 0.05)$ in AST, ALT, and ALP levels comparing with the positive control group. Regarding to ALT, no significant difference between the effect of supplemented diets with VCO and MOO was noted. On the other hand, the supplement with MOO lowest decline both AST and ALP levels, followed by VCO.

Table 2. Effect of soybean, virgin coconut and M. oleifera seed oils on thyroid hormones concentration in rats suffer from hypothyroidism.

\begin{tabular}{lccc}
\hline Groups & $\begin{array}{c}\text { TSH } \\
(\boldsymbol{\mu I U} / \mathbf{m L})\end{array}$ & $\begin{array}{c}\text { FT3 } \\
(\mathbf{p g} / \mathbf{m L})\end{array}$ & $\begin{array}{c}\text { FT4 } \\
(\mathbf{n g} / \mathbf{d L})\end{array}$ \\
\hline Control (-ve) & $0.95 \pm 0.09^{\mathrm{d}}$ & $4.73 \pm 0.17^{\mathrm{a}}$ & $3.56 \pm 0.12^{\mathrm{a}}$ \\
Control (+ve) & $5.23 \pm 0.49^{\mathrm{a}}$ & $1.85 \pm 0.06^{\mathrm{e}}$ & $1.60 \pm 0.08^{\mathrm{e}}$ \\
Soybean oil (SO) & $3.83 \pm 0.27^{\mathrm{b}}$ & $2.86 \pm 0.07^{\mathrm{d}}$ & $2.36 \pm 0.12^{\mathrm{d}}$ \\
Virgin coconut oil (VCO) & $2.96 \pm 0.07^{\mathrm{c}}$ & $3.52 \pm 0.14^{\mathrm{c}}$ & $2.75 \pm 0.11^{\mathrm{c}}$ \\
M. oleifera seeds oil (MOO) & $2.48 \pm 0.07^{\mathrm{c}}$ & $4.05 \pm 0.05^{\mathrm{b}}$ & $3.21 \pm 0.07^{\mathrm{b}}$ \\
\hline
\end{tabular}

Mean values are expressed as means \pm SD.

Means with different superscript letters in the column are significantly different at $\mathrm{P} \leq 0.05$. 
Table 3. Effect of soybean, virgin coconut and $M$. oleifera seed oils on liver functions in rats suffer from hypothyroidism

\begin{tabular}{|c|c|c|c|}
\hline $\begin{array}{ll}\text { Groups } & \text { Parameters } \\
\end{array}$ & $\begin{array}{l}\text { ALT } \\
(\mu / \mathbf{L})\end{array}$ & $\begin{array}{l}\text { AST } \\
(\mu / L)\end{array}$ & $\begin{array}{l}\text { ALP } \\
(\mu / \mathbf{L})\end{array}$ \\
\hline Control (-ve) & $27.15 \pm 1.38^{\mathrm{d}}$ & $70.10 \pm 1.05^{\mathrm{e}}$ & $199.25 \pm 0.75^{\mathrm{d}}$ \\
\hline Control (+ve) & $50.40 \pm 1.28^{\mathrm{a}}$ & $95.75 \pm 2.49^{\mathrm{a}}$ & $235.52 \pm 2.37^{a}$ \\
\hline Soybean oil (SO) & $41.20 \pm 1.29^{\mathrm{b}}$ & $88.82 \pm 1.16^{\mathrm{b}}$ & $223.47 \pm 2.40^{b}$ \\
\hline Virgin coconut oil (VCO) & $35.12 \pm 0.82^{\mathrm{c}}$ & $82.25 \pm 1.25^{\mathrm{c}}$ & $218.05 \pm 1.99^{b}$ \\
\hline M.oleifera seeds oil (MOO) & $36.50 \pm 1.57^{\mathrm{c}}$ & $75.70 \pm 1.63^{\mathrm{d}}$ & $208.80 \pm 1.19^{c}$ \\
\hline
\end{tabular}

Mean values are expressed as means \pm SD.

Means with different superscript letters in the column are significantly different at $\mathrm{P} \leq 0.05$.

Thyroid hormones control the basal metabolic rate of all body cells including hepatocytes and thus modulate the function of the liver. In exchange, the liver metabolizes thyroid hormones and controls their endocrine systemic effects. Therefore, thyroid dysfunction may disturb liver function (Khan et al., 2010). Our findings are consistent with Carrion et al. (2010) who recorded a positive relationship between thyroid hormones and liver enzymes. Thyrotoxicosis is generally associated with a variety of liver dysfunction. Nishimura et al. (2006) showed that soybean oil prevents liver damage. It is stressed that soybean oil positively controled the amount of blood and lipids in liver (Lin et al.,2005). Generally, the elimination of lipid peroxidation by natural dietary antioxidants has been correlated with hypolipidemic (Abhilash et al.,2011).

According to Siddalingaswamy et al. (2011) and Pretha et al. (2013), VCO ables to positively influence liver functions. Rabeh and El-Ghandour (2016) and Aisuodionoe et al. (2018) reported that VCO improves metabolic parameters, antioxidant enzyme activities, reduces oxidative stress and lipid peroxidation in diabetes. Famurewa et al. (2018) mentioned that beneficial effects of VCO on lipid profile, antioxidant hepatic defense system, and cardiovascular risk indices in rats. Hamza (2010) revealed that treatment with moringa seed extract can significantly reduce the indices of hepatotoxicity. Fakurazi et al. (2008) and Paliwal et al. (2011) stated that moringa seed oil has been used as an indigenous medicine for cardiac care, gastrointestinal, haematological and hepatorenal disorders. Sheikh et al. (2014) reported that both ethanol moringa leaves and seeds extracts reduced arsenicinduced elevation of liver activities. These findings are in accordance with Nada et al. (2015), Toppo et al. (2015) and Habib \& Al-Moalem (2018).

The levels of TC, TG, LDL-c and VLDL-c increased significantly and HDL-c decreased by PTU injection into rats $(\mathrm{P} \leq 0.05)$ compared with the negative control group, as shown inTable (4). The supplementation with SO, VCO and MOO caused a significant $(\mathrm{P} \leq 0.05)$ decrease in TC, TG, VLDL-c, LDL-c and HDL-c significant increase than the positive control group. Both VCO and MOO had nearly the same effect on the determined parameters. Also, no significant changes in the HDL and LDL levels were observed due to type of oil intake. The opposite trend was noted between the mean value of serum TG and VLDL among the treated groups. The high reduction in lipid profile was observed in the group fed with MOO.

Table 4. Effect of soybean, virgin coconut and M. oleifera seed oils on lipid profile in rats suffer from hypothyroidism.

\begin{tabular}{lccccc}
\hline \multicolumn{1}{c}{ Parameters } & $\begin{array}{c}\text { TC } \\
(\mathbf{m g} / \mathbf{d l})\end{array}$ & $\begin{array}{c}\text { TG } \\
(\mathbf{m g} / \mathbf{d l})\end{array}$ & $\begin{array}{c}\text { HDL-c } \\
(\mathbf{m g} / \mathbf{d l})\end{array}$ & $\begin{array}{c}\text { LDL-c } \\
(\mathbf{m g} / \mathbf{d l})\end{array}$ & $\begin{array}{c}\text { VLDL-c } \\
(\mathbf{m g} / \mathbf{d l})\end{array}$ \\
\hline Croups & $123.25 \pm 2.01^{\mathrm{d}}$ & $61.15 \pm 1.97^{\mathrm{e}}$ & $47.75 \pm 1.65^{\mathrm{a}}$ & $63.27 \pm 3.28^{\mathrm{d}}$ & $12.23 \pm 0.39^{\mathrm{e}}$ \\
Control (-ve) & $166.82 \pm 2.51^{\mathrm{a}}$ & $92.90 \pm 1.87^{\mathrm{a}}$ & $29.07 \pm 0.88^{\mathrm{d}}$ & $119.17 \pm 2.02^{\mathrm{a}}$ & $18.58 \pm 0.37^{\mathrm{a}}$ \\
Soybean oil & $152.95 \pm 2.17^{\mathrm{b}}$ & $86.42 \pm 1.43^{\mathrm{b}}$ & $39.20 \pm 0.82^{\mathrm{bc}}$ & $96.46 \pm 3.09^{\mathrm{b}}$ & $17.28 \pm 0.28^{\mathrm{b}}$ \\
Virgin coconut oil & $144.02 \pm 2.95^{\mathrm{c}}$ & $79.67 \pm 2.39^{\mathrm{c}}$ & $36.92 \pm 1.56^{\mathrm{c}}$ & $91.16 \pm 2.69^{\mathrm{b}}$ & $15.93 \pm 0.47^{\mathrm{c}}$ \\
M.oleifera seeds oil & $138.75 \pm 1.79^{\mathrm{c}}$ & $71.10 \pm 2.76^{\mathrm{d}}$ & $42.32 \pm 0.97^{\mathrm{b}}$ & $82.20 \pm 0.51^{\mathrm{c}}$ & $14.22 \pm 0.55^{\mathrm{d}}$ \\
\hline
\end{tabular}

Mean values are expressed as means \pm SD.

Means with different superscript letters in the column are significantly different at $\mathrm{P} \leq 0.05$. 
The current results are in accordance with Abdou et al. (2018) who displayed that soybean oil, can be used as a hypolipidemic agent. Siddalingaswamy et al. (2011) found that VCO improved lipid profile and antioxidant status by enhancing antioxidant enzyme activity such as SOD and decresed lipid peroxidation in liver. Rahim et al. (2017) and Rabeh (2017) showed that VCO lowered TC, TG, LDL, VLDL and increased HDL. Similar result was consistent with Hima et al. (2019) who showed that VCO had hypolipidemic effect on rats which elevated high density lipoprotein cholesterol (HDL-c) and reduced level of triacylglycerol (TG). The current findings are in line with Mehta et al. (2003) and Ara et al. (2008).They observed that M. oleifera lowered serum cholesterol, triglyceride, VLDL, LDL and increased HDL. Concomitant to this finding, Pankaj et al. (2010) and Khanna et al. (2015) observed that M. oleifera caused a temporary reduction in the level of the liver enzymes and prevent liver damage from a high-fat meal.

Table (5) reveales the impact of supplementing soybean, virgin coconut and M.oleifera seed oils on antioxidant enzymes MDA and SOD in rats. The positive control group showed a significant increase $(\mathrm{P} \leq 0.05)$ in the serum MDA value and a decrease in the level of SOD compared with the negative control group. The supplementation with SO, VCO and MOO decreased the mean level of serum MDA and increased serum SOD compared to the positive control group. MOO supplementation was also able to reduce MDA levels in contrast with the normal group levels. No significant difference was observed in serum level of SOD between the groups fed on diet supplemented with SO and VCO. The best concentrations of SOD and MDA were recorded for group fed on MOO.

Malondialdehyde (MDA) is an oxidative stress marker that can be used to measure the extent of lipid peroxidation (Gawel et al., 2004). In hypothyroid subjects, MDA level was found to be higher in oxidative stress (Lakshmi et al., 2013). Excess TSH causes oxidative stress. Our results showed rise in MDA level due to hypothyroidism induced oxidative stress and decrease in the values of SOD and also the results of Haribabu et al. (2013) showed the same trend. Free radical scavenging enzymes like SOD are the first line of cell defense against oxidative injury and are involved in the elimination of superoxide anions, hydrogen peroxide, etc. (Vijayaraj et al. 2013). Phytoestrogens can play an antioxidant role not only by breaking down reactive oxygen species, but also by stimulating antioxidant enzyme activity (Taha et al., 2014).

Ironically, in this study, the antioxidant properties of oils (soybean, virgin coconut and M.oleifera seeds) were also observed by reducing lipid peroxides (MDA) and elevating endogenous antioxidant enzymes (SOD). The decrease in lipid peroxidation indicates that soybean oil counteracts the deleterious effects of lipid peroxidation (Cheng and Kong, 2011). Furthermore, Mallo et al. (2013) reported that soybean flavonoids, have gained importance as free radical scavengers and as a potent lipid peroxidation inhibitor.

Marina et al. (2009) and Yeap et al. (2015) demonstrated the antioxidative potential and powerful countermeasures of VCO polyphenols against lipid peroxidation in tissues. Iranloye et al. (2013) suggested that VCO reduces oxidative stress by boosting the antioxidant defense system, scavenging free radicals and reducing lipid peroxidation; another independent study suggested that fresh coconut oil can reduce oxidative stress associated with diabetes mellitus. Famurewa et al. (2018) showed that VCO decreased malondialdehyde (MDA) levels, and increased activities of hepatic antioxidant enzymes superoxide dismutase (SOD). Virgin coconut oil contains high unsaponifiable lipid components like vitamin $\mathrm{E}$ and polyphenols, tocotrienols, tocopherols, $\beta$ carotene and phytosterol in stabilising cell membranes by preventing alterations in membrane lipid polarity and fluidity (Jaarin et al., 2014).

Table 5. Effect of soybean, virgin coconut and M. oleifera seed oils on antioxidant enzymes MDA and SOD in rats suffer from hypothyroidism.

\begin{tabular}{lcc}
\hline \multicolumn{1}{c}{ Parameters } & $\begin{array}{c}\text { MDA } \\
(\mathbf{n m o l} / \mathbf{m l})\end{array}$ & $\begin{array}{c}\text { SOD } \\
(\boldsymbol{\mu} / \mathbf{d l})\end{array}$ \\
\hline Groups & $10.52 \pm 0.65^{\mathrm{d}}$ & $68.60 \pm 1.31^{\mathrm{a}}$ \\
Control (-ve) & $45.27 \pm 2.03^{\mathrm{a}}$ & $25.30 \pm 2.44^{\mathrm{d}}$ \\
Soybean oil (SO) & $31.75 \pm 1.28^{\mathrm{b}}$ & $33.52 \pm 1.60^{\mathrm{c}}$ \\
Virgin coconut oil (VCO) & $20.27 \pm 0.89^{\mathrm{c}}$ & $37.35 \pm 1.34^{\mathrm{c}}$ \\
M. oleifera seeds oil (MOO) & $13.76 \pm 2.05^{\mathrm{d}}$ & $48.87 \pm 1.66^{\mathrm{b}}$ \\
\hline
\end{tabular}

Mean values are expressed as means \pm SD.

Means with different superscript letters in the column are significantly different at $\mathrm{P} \leq 0.05$. 
The current results are in accordance with Sreelatha and Padma (2009) who observed that treatment with M.oleifera extract was significantly reduced serum MDA level. This could be attributed to its high polyphenol contact. Toppo et al. (2015) results, indicated that $M$. oleifera significantly increased the levels of SOD to $500 \mathrm{mg} / \mathrm{kg}(\mathrm{p} \leq 0.01)$.

\section{CONCLUSION}

The studied oils have prophylactic potential against thyroid dysfunctions and the subsequent oxidative stress, as well as improvements in liver function and lipid profile. So, the present findings inferred that the treatment with soybean, virgin coconut and M.oleifera seed oils could be used as a potential strategy for the treatment for patients with hypothyroidism.

\section{REFRENCES}

Abarikwu, S., S. Benjamin, S. Ebah, G. Obilor and G. Agbam. 2017. Protective effect of Moringa oleifera oil against $\mathrm{HgCl} 2$-induced hepato- and nephro-toxicity in rats. Journal of Basic and Clinical Physiology and Pharmacology. 28: 337-345.

Abdou, H., M. Yousef and A. Newairy. 2018. Triton WR1339-induced hyperlipidemia, DNA fragmentation, neurotransmittersinhibition, oxidative damage, histopathological and morphometricchanges: the protective role of soybean oil. The Journal of Basic and Applied Zoology.79:51.

Abhilash, P., P. Nisha, A. Prathapan, S.V. Nampoothiri, O. Lijo- Cherian, T. Sunitha and K. Raghu. 2011. Cardioprotective effects of aqueous extract of Oxalis corniculata in experimental myocardial infarction. Experimental and Toxicologic Pathology. 63(6):535-540.

Aisuodionoe, E., O. Odigie, A. Naiho, M. Oyovwi and J. Igweh. 2018. Hepatic, renal, and anti-oxidant function markers can improve in dose-dependent administration of fresh coconut oil. Asian Journal of Research in Medical and Pharmaceutical Sciences. 3(3), 1-12.

Albers, N., V. Benderson and G. Warnick. 1983. Enzymatic determination of high density lipoprotein cholesterol, Selected Methods, Clin. Chem., 10:91-99.

AOAC. 2005. Official methods of analysis of AOAC international. $18^{\text {th }}$ ED., AOAC international Gaithersburg, MD, USA

Ara, N., M. Rashid and M. Amran. 2008. Comparison of Moringa oleifera leaves extract with ethanol on serum triglyceride, seru cholesterol, blood glucose, heart weight, body weight in adrenaline induced rats. Saudi J Bio Sci. 15(2):253-258.

Bagcchi, S. 2014. Hypothyroidism in India: more to be done. Lancet Diabetes Endocrinol. 2(10):778.

Belfield, A. and D. Goldberg. 1971. Revised assay for serum phenyl phosphatase activity using 4- aminoantipyrineenzyme. 12: 561-573.
Bergmeyer, H., P. Schreiber and A.Wahlefeld. 1978. Optimization of methods for aspartate and alanine aminotransferase. Clinical Chemistry.24: 58-61.

Bertram, GK. 2012. Thyroid and antithyroid drugs In: Shafiei A, ed. Basic and Clinical Pharmacology. Thehran: Andishe Rafih; 883.

Bhanja, S. and G. Chainy. 2010. PTU-induced hypothyroidism modulates antioxidant defence status in the developing cerebellum. Neuroscience.28 (3): 251-62.

Bitto, A., F. Polito, M. Atteritano, D. Altavilla, S. Mazzaferro, H. Marini, E. Adamo, R. D'Anna, R. Granese, F. Corrado, S. Russo, L. Minutoli and F. Squadrito. 2010. Genistein aglycone does not affect thyroid function: results from a three-year, randomized, double-blind, placebo-controlled trial. J Clin Endocrinol Metab. 95(6): 3067-72.

Burnett, C., W. Bergfeld, D. Belsito, C. Klaassen, J. Marks, R. Shank, T. Slaga, P. Snyder and F. Andersen. 2011. Final report on the safety assessment of Cocos nucifera (coconut) oil and related ingredients. Int J Toxicol.30 (3 Suppl):5S-16S.

Carrion, A., F. Czul, L. Arosemena, G. Selvaggi, M. Garcia, A.Tekin, A.Tzakis, P. Martin and R. Ghanta. 2010. Propylthiouracil-induced acute liver failure: role of liver transplantation. Int J Endocrinol. 910636, 5 pages.

Cederroth, C., C. Zimmermann and S. Nef. 2012. Phytoestrogens and their impact on reproductive health. Mol Cell Endocrinol. 22; 355(2):192 200.

Chaker, L., A. Bianco, J. Jonklaas and R. Peeters. 2017. Hypo-thyroidism. Lancet. 390: 1550-1562.

Chakrabarti, S., S. Ghosh, S. Banerjee, S. Mukherjee and S. Chowdhury. 2016. Oxidative stress in hypothyroid patients and the role of antioxidant supplementation. Indian J Endocrinol Metab. 20 (5):674-678.

Che-Man, Y.B. and A.M. Marina. 2006. Medium chain triacylglycerol. In: Nutraceutical and specialty lipids and their co-products, Shahidi, F., Ed.; CRC Press, Boca Raton, FL, pp:27-56.

Cheng, D. and H. Kong.2011. The effect of Lycium barbarum poly-saccharide on alcohol-induced oxidative stress in rats. Molecules. 16(3): 2542-2550.

Deol, P., J. Evans, J. Dhahbi, K. Chellappa, D. Han, S. Spindler and F. Sladek. 2015. Soybean Oil Is More Obesogenic and Diabetogenic than Coconut Oil and Fructose in Mouse: Potential Role for the Liver. PLoS ONE. 10(7): e0132672.

Dillingham, B., B. Mc-Veigh, J. Lampe and A. Duncan. 2007. Soy protein isolates of varied isoflavone content do not influence serum thyroid hormones in healthy young men.Thyroid. 17:131-137.

Dons, R.F. and F.H. Wians. 2009. Endocrine and Metabolic Disorders Clinical Lab Testing Manual. (4th ed.), Boca Raton: CRC Press. P: 10.

Draper, H. and M. Hadley. 1990. Malondialdehyde determination as index of lipid peroxidation. Methods Enzymol.186: 421-431. 
Emsley, R., G. Dunn and I. White. 2010. Mediation and moderation of treatment effects in randomized controlled trials of complex interventions. Stat Methods Med Res. 19: $237-270$.

Fakurazi, S., I. Hairuszah and U. Nanthini. 2008. Moringa Oleifera Lam prevents acetaminophen induced liver injury through restoration of glutathione level. Food Chem Toxicol. 46(8):2611-2615.

Famurewa, A., P. Aja, E. Maduagwuna, C. Ekeleme-Egedigwe، O.G. Ufebe and S. Azubuike-Osu. 2017. Antioxidant and anti-inflammatory effects of virgin coconut oil supplemen- tation abrogate acute chemotherapy oxidative nephrontoxicity induced by anticancer drug methotrexate in rats. Biomedicine and Pharmacotherapy. 96, 905-911.

Famurewa, A. P. Aja, O. Nwankwo, J. Awoke, E. Maduagwuna and C. Aloke. 2019. Moringa oleifera seed oil or virgin coconut oil supplementation abrogates cerebral neurotoxicity induced by antineoplastic agent methotrexate by suppression of oxidative stress and neuro inflammation in rats. J Food Biochem.43:e12748.

Famurewa, A., C. Ekeleme-Egedigwe, S. Nwali, N. Agbo, J. Obi and G. Ezechukwu. 2018. Dietary supplementation with virgin coconut oil improves lipid profile and hepatic antioxidant status and has potential benefits on cardiovascular risk indices in normal rats. J Diet Suppl. 15(3): 330-342.

Feranil A., P. Duazo, C. Kuzawa and L. Adair. 2011. Coconut oil is associated with a beneficial lipid profile in premenopausal women in the Philippines. Asia Pac. J. Clin. Nutr. 20(2), 190-195.

Fossati, P. and L. Praneipe. 1982. Enzymatic colorimetric method to determination triglycerides. Clin Chem. 28: 2077-80.

Fruchart, GG. 1982. LDL-cholesterol determination after separation of low density lipoprotein. Rev Fr Des Laboratories. 103(7):117.

Fumarola, A., A. Di-Fiore, M. Dainelli, G. Grani and A. Calvanese. 2010. Medical treatment of hyperthyroidism: state of the art. Exp Clin Endocrinol.118:678-684.

Gawel, S., M. Wardas, E. Niedworok and P. Wardas. 2004. Malondialdehyde (MDA) as a lipid peroxidation marker. Wiadomosci lekarskie (Warsaw Poland:1960), 57(9-10): 453-455.

Gupta, S., R. Jaina, S. Kachhwahab and S. Kotharic. 2018. Nutritional and medicinal applications of Moringa oleifera Lam.-Review of current status and future possibilities. $J$. Herb. Med.11: 1-11.

Gupta, V., L. Walia, S. Gupta and N. Bajwa. 2009. Comparison of the effects of coconut oil and soyabean oil on TSH level and weight gain in rabbits. Online J Health Allied Scs. 8:1-7.

Habib, M.K. and M.H. Al-Moalem. 2018. Effect of Moringa Leaves and Seeds on Osteoporosis in Rats. J. Food and Dairy Sci. 9 (10): 129 - 135.
Hamza, A.A. 2010. Ameliorative effects of Moringa oleifera Lam seed extract on liver fibrosis in rats. Food Chem Toxicol. 48(1):345- 55.

Haribabu, A., V. Reddy, C. Pallavi, A. Bitla, A. Sachan, P. Pullaiah, V. Suresh, P. Rao and M. Suchitra. 2013. Evaluation of protein oxidation and its association with lipid peroxidation and thyrotropin levels in overt and subclinical hypothyroidism. Endocrine. 44 (1):152-7.

Hayes, K. and Khosla, P. 2007. The complex interplay of palm oil fatty acids on blood lipids. European Journal of Lipid Science and Technology.109:453-464.

Hima, L., U. Pratap, S. Karrunanithi, K. Ravichandran, R.Vasantharekha and S. Thyaga-Rajan. 2019. Virgin coconut oil supplementation in diet modulates immunity mediated through survival signaling pathways in rats. $\mathbf{J}$ Complement Integr Med. doi: 10.1515/jcim-2019-0114. [Epub ahead of print].

Iranloye, B. 2013. Photomeric assay for superoxide dismutase based on epi nephrine autooxidation. Analytical Biochemistry Analytical Biochemistry. 90: 81-89.

Iranloye, B., G. Oludare and M. Olubiyi. 2013. Anti-diabetic and antioxidant effects of virgin coconut oil in alloxan induced diabetic male Sprague Dawley rats. Journal of Diabetes Mellitus. 3(4): 221-226.

ISO 12966-4:2015(en). Animal and vegetable fats and oilsGas chromatography of fatty acid methyl esters-Part 4: Determination by capillary gas chromatography.

Jaarin, K., M. Norliana, Y. Kamisah, M. Nursyafiza and H. Mohd. 2014. Potential role of virgin coconut oil in reducing cardiovascular risk factors. Experimental and Clinical Cardiology. 20(8): 3399-3410.

Jacobs, N. and P.Vander.1960. Determination of serum triglycerol. Arch. Biochem. Biophs. 88: 250.

Kakkar, P., B.Das and P. Synder. 1984. A modified spectrophotometric assay of superoxide dismutase. Ind. J. Biochem. Biophys. 21: 131-132.

Khan, T., S. Malik and I, Diju. 2010. Correlation between plasma thyroid hormones and liver enzyme level in thyrotoxic cases and control in hazara division. J. Ayub Med. Coll. Abbottabad. 22(2): 176-179.

Khanna, S., N. Raj and K. Aparna. 2015. Moringa oleifera and obesity: A review. International Journal of Advanced Research in Engineering and Applied Sciences. 4 (11); 123.

Kou, X., B. Li, J. Olayanju, J. Drake and N. Chen. 2018. Nutraceutical or pharmaco-logical potential of Moringa oleifera Lam. Nutrients. 10: 3. 10.3390/nu 10030343.

Krishna, G. G. Raj, A. Bhatnagar and P. Chandrashekar. 2010. Coconut oil: chemistry, production and its applications - A Review. Indian Coconut Journal.7: 15-27.

Lakshmi, L., M. Eli, Z. Doddigarla and K. Suchitra. 2013. Serum lipids and oxidative stress in hypothyroidism. J Adv Res Biol Sci. 5(1):63-6. 
Leone, A., A. Alberto Spada, A. Battezzati, A. Alberto Schiraldi, J. Aristil and S. Bertoli. 2016. Moringa oleifera Seeds and Oil: Characteristics and Uses for Human Health. Int. J. Mol. Sci. 17, 2141.

Li, J., X. Teng, W. Wang, Y. Chen, X. Yu, S. Wang, J. Li, L. Zhu, C. Li, C. Fan, H. Wang, H. Zhang, W. Teng and Z. Shan. 2011. Effects of dietary soy intake on maternal thyroid functions and serum antithyroperoxidase antibody level during early pregnancy. J Med Food.14 (5): 543-50.

Lin, C.Y., C.Y. Tsai and S.H. Lin. 2005. Effects of soy components on blood and liver lipids in rats fed highcholesterol diets. World Journal of Gastroenterology. 11, 5549 .

Lin, M., J. Zhang and X. Chen. 2018. Bioactive flavonoids in Moringa oleifera and their health-promoting properties. J. Funct. Foods.47: 469-479.

Louzada, R.A. and D.P. Carvalho. 2018. Similarities and differences in the peripheral actions of thyroid hormones and their metabolites. Front. Endocrinol. 9. 10.3389/ fendo. 00394.

Mallo, M., M. Mabrouk, Y. Tanko and P. Mshelia. 2013. Effects of soya bean oil and vitamin $\mathrm{C}$ on lipid peroxidation and antioxidant biomarkers ethanol-induced oxidative stress in Wistar rats. Journal of Pharmacy and Biological Sciences.4 (6):28-31.

Marina, A., Y. Man, S. Nazimah and I. Amin. 2009. Antioxidant capacity and phenolic acids of virgin coconut oil. Int J Food Sci Nutr. 60(2):114-23.

Mehta, K., R. Balaraman, A. Amin, P. Bafna, and O. Gulati. 2003. Effect of fruits of Moringa oleifera on the lipid profile of normal and hypercholesterolaemic rabbits. J Ethnopharmacol.86 (2-3): 191-195.

Modaresi, M., H. Khorrami and M. Asadi-Samani. 2014. The effect of feeding with soybean on serum levels of TSH, T3 and T4 in male mice. J HerbMed Pharmacol., 3(2):93-96.

Mohamed, D., SH. Abdelgayed, R. Mohamed and H. Essa. 2019. Impact of safflower petals and moringa leaves extracts in experimental hyper and hypothyroidism in rats. Int. J. Pharmacol., 15(2): 219-228.

Nada, SH., M. Hashem, M. Abbas, A. Soliman and F. Ahmed. 2015. Evaluation of Moringa oleifera leaves extract effects on streptozotocin-induced diabetic rats. Advances in Food Sciences. 37(3): $86-95$.

Nair, R., L. Joseph and T. Rahees. 2015. Role of Ethanolic Extract of Bauhinia purpurea leaves on amelioration of hyperthyroidism in LT4 induced female albino wistar rats. J Pharmacol Toxicol Stud: Res Rev. 3(4):1-10.

Nevin, K.G. and T. Rajamohan. 2008. Beneficial effects of virgin coconut oil on lipid parameters and in vitro LDL oxidation. Clin Biochem. 37 (9): 830-5.

Nevin, K. and T. Rajamohan. 2006. Virgin coconut oil supplemented diet increases the antioxidant status in rats. Food Chemistry.99: 260-266.
Nishimura, M., M. Yamaguchi, S. Naito and A. Yamauchi. 2006. Soybean oil fat emulsion to prevent TPN-induced liver damage: possible molecular mechanisms and clinical implications. Biological and Pharmaceutical Bulletin. 29(5): 855-862.

Ogedengbe, O., E. Naidu, E. Akang, U. Offor, I. Onanuga, A. Peter and O. Azu. (2018). Virgin coconut oil extract mitigates testicular-induced toxicity of alcohol use in antiretroviral therapy. Andrology, https://doi.org/10.1111/andr.12490.

Ogunsina, B.S.; T.N. Indira, A.S. Bhatnagar, C. Radha, S. Debnath, A.G. Gopala- Krishna. 2014. Quality characteristics and stability of Moringa oleifera seed oil of Indian origin. J. Food Sci. Technol. 51،503-510.

Olatosin, T., D. Akinduko and C. Uche. 2013. Evaluation of the hepato-protective efficacy of Moringa oleifera seed oil on CCl4- induced liver damage in Wistar albino rats. International Journal Engeneering Science. 2: 13-18.

Ott, J., R. Promberger, F. Kober, N. Neuhold, M. Tea, J.C. Huber, and M. Hermann. 2011. Hashimoto's thyroiditis affects symptom load and quality of life unrelated to hypothyroidism: a prospective case-control study in women undergoing thyroidectomy for benign goiter. Thyroid. 21(2):161-7.

Otun, J., A. sahebkar, L. Ostlundh, S. Atkin and T. Sathyapalan. 2019. Systematic review and metaanalysis on the efect of soy on thyroid function. Scientific RepoRts.9:3964. https://doi.org/10.1038/s41598-019 40647-x

Paliwal, R., V. Sharma and Pracheta. 2011. A review on horse radish tree (Moringa oleifera): A multipurpose tree with high economic and commercial importance. Asian $\mathrm{J}$ Biotechnol. 3(4):317- 328.

Pankaj, G. J., D.P.Savita, G.H. Nitin, V.G. Manoj, J.S. Sanjay. 2010. Hypolipidemic activity of Moringa oleifera Lam., Moringaceae, on high fat diet induced hyperlipidemia in albino rats. Rev. bras. Farmacogn. 20 (6) Curitiba Epub Nov 12.

Pretha, P., V. Girija- Devi and T. Rajamohan. 2013. Comparative effects of mature coconut water (Cocos nucifera) and glibenclamide on some biochemical parameters in alloxan induced diabetic rats. Rev. bras. farmacogn.23(3): 481-487.

Rabeh, N.M. 2017. Effect of virgin coconut oil, curcumin and vitamin $\mathrm{D}$ supplementation on rats with induced hypothyroidism. Journal of Home Economics. 27(2):1-21.

Rabeh, N.M and H.A. El-Ghandour. 2016. Effect of iron, zinc, vitamin $\mathrm{E}$ and vitamin $\mathrm{C}$ supplementation on thyroid hormones in rats with hypothyroidism. Int. J. Nutr. Food Sci., 5(3): 201-210.

Rahim, N., S. Lim, V. Mani, A. Majeed and K. Ramasamy. 2017. Enhanced memory in Wistar rats by virgin coconut oil is associated with increased antioxidative, cholinergic activities and reduced oxidative stress. Pharmaceutical Biology.55: 825-832. 
Rahman, F., M. Nadeem, M. Azeem and Y. Zahoor. 2014 Comparison of the chemical characteristics of high oleic fraction of Moringa oleifera oil with some vegetable oils. Pakistan Journal of Analytical and Environmental Chemistry.15: 80-83.

Reeves, R., F. Nielsen and G. Fahey. 1993. AIN-93 Purified Diets for Laboratory Rodents .J. Nutr. 123(1):1939-1951.

Retana-Marquez, S., H. Hernandez, J. Flores, M. MuñozGutiérrez, G. Duarte, J. Vielma, G. Fitz-Rodríguez, I. Fernández, M. Keller and J. Delgadillo. 2012. Effect of phytoestrogens on mammalian reproductive physiology.Tropical and Subtropical Agroecosystems. 15(1):129-145.

Saa, R., E. Fombang, E. Ndjantou and N. Njintang. 2019. Treatments and uses of Moringa oleifera seeds in human nutrition: A review. Food Sci Nutr.7:1911-1919

Sarathi, V., A. Kolly, H. Chaithanya and C. Dwarakanath. 2016. Effect of soya based protein rich diet on glycaemic parameters and thyroid function tests in women with gestational diabetes mellitus. Rom J Diabetes Nutr Metab Dis. 23(2):201-208.

Sathyapalan, T., A. Manuchehri, N. Thatcher, A. Rigby, T. Chapman, E. Kilpatrick and S. Atkin. 2011. The effect of soy phytoestrogen supplementation on thyroid status and cardiovascular risk markers in patients with subclinical hypothyroidism: a randomized, double-blind, crossover study.J Clin Endocrinol Metab. 96(5):1442-9.

Sener, G., L. Kabasakal, B. Atasoy, C. Erzik, A.VeliogluOgunç, S. Cetinel, G. Contuk, N. Gedik and B. Yegen. 2006. Propylthiouracil induced hypothyroidism protects ionizing radiation induced multiple organ damage in rats. Journal of Endocrinology. 189: 257-269.

Shamsian, A., K. Ghazvini, M. Sokhtanloo, M. Moghaddam and R. Vakili. 2016. Which quantitative method in determination of the thyroid hormone levels is more consistent with the clinical symptoms of the thyroid disorders? Comp Clin Path. 25(1):101-6.

Sharma, A., S. Devi, K. Singh and P. Prabhakar. 2018. Correlation of body mass index with thyroid-stimulating hormones in thyroid patient. Asian J. Pharm. Clin. Res. 11: 65-68.

Sheikh,A., F. Yeasmin, S. Agarwal, M. Rahman, K. Islam, E. Hossain, S. Hossain, M.R. Karim, F. Nikkon, Z.A. Saud and K. Hossain. 2014. Protective effects of Moringa oleifera Lam. leaves against arsenic-induced toxicity in mice. Asian Pac J. Trop Biomed. 4 (Suppl 1): 353-358.

Shu, X., Y. Zheng, H. Cai, K. Gu, Z.Chen, W. Zheng and W. Lu. 2009. Soy food intake and breast cancer survival. JAMA. 302(22) :2437-2443.

Siddalingaswamy, M., A. Rayaorth and F. Khanum. 2011. Anti-diabetic effects of cold and hot extracted virgin coconut oil. Journal of Diabetes Mellitus. 1(4): 118-123.

Sreelatha, S. and P. Padma. 2009. Antioxidant activity and total phenolic content of Moringa oleifera leaves in two stages of maturity. Plant Foods Hum Nutr. 64(4): 303-311.
Sue, M., T. Akama, A. Kawashima, H. Nakamura, T. Hara, K. Tanigawa, H. Wu, A. Yoshihara, Y. Ishido, N. Hiroi, G. Yoshino, L. Kohn, N. Ishii and K. Suzuki. 2012. Propylthiouracil increases sodium/iodide symporter gene expression and iodide uptake in rat thyroid cells in the absence of TSH. Thyroid. 22(8):844-852.

Tabassum, W., A. Kullu and M. Sinha. 2013. Effect of leaf extracts of moringa oleifera on regulation of hypothyroidism and lipid profile. The Bioscan. Supplement on Medicinal Plants. 8(2): 665-9.

Taha, N., A. Mandour and M. Lebda. 2014. Antioxidative and cardio-protective effects of ethanolic extract of ginger on triton WR-1339 induced hyperlipidemia in rats. International Journal of Chemical Research. 6(1): 153-158.

Takeuchi, H., S. Sekine, K. Kojima and T. Aoyama. 2008. The application of medium chain fatty acids: Edible oil with a suppressing effect on body fat accumulation. Asia Pacific Journal of Clinical Nutrition.17: 320-324.

Toppo, R., B. Roy, R. Gora, S. Baxla and P. Kumar. 2015. Hepato-protective activity of Moringa oleifera against cadmium toxicity in rats.Vet. World. 8(4): 537-540.

Vijayaraj, P., K. Muthukumar, J. Sabarirajan and V. Nachiappan. 2013. Antihyper-lipidemic activity of Cassia auriculata flowers in triton WR 1339 induced hyperlipidemic rats. Experimental and Toxicologic Pathology. 65 (1-2):135-141.

Warner, K. 2005. Effects on the flavor and oxidative stability of stripped soybean and sunflower oils with added pure tocopherols. Journal of Agricultural and Food Chemistry. 53(26): 9906-9910.

Wazida, T., R. Arunaand M. Sinha. 2013. Effects of leaf extracts of Moringa oleifera on regulation of hypothyroidism and lipid profile. The Bioscan. 8(2):665669.

Wu, N., X. Yang, Z. Teng, S. Yin, J. Zhu and J. Qi. 2011. Stabilization of soybean oil body emulsions using $\kappa, 1, \lambda$ carrageenan at different PH values, Food Res. Int. 44(4): 1059-1068.

Yeap, S., B. Beh, N. Ali, H. Yusof, W. Ho, S. Koh, N. Alitheen and K. Long. 2015. Antistress and antioxidant effects of virgin coconut oil in vivo. Exp Ther Med. 9 (1):39-42.

Zainuddin, A., M. Massi, G. Alam, K. Djawad and I. Yusuf. 2015. Soybean protective effect to $8-\mathrm{OHdG}$ on UVB induced-hairless mice. American Journal of Medical and Biological Research.3: 146-148.

Zilic, S., A. Serpen, G. Akyllyoglu, M. Jankovic and V. Gokmen. 2012. Distributions of phenolic compounds, yellow pigments and oxidative enzymes in wheat grains and their relation to antioxidant capacity of bran and debranned flour. Journal of Cereal Science. 56: 652-658. 


\section{الملخص العربي}

\section{تأثير زيوت فول الصويا وجوز الهند البكر وبذور المورينجا على قصور الغدة الدرقية الناجم عن البروبيل ثيور اسيل في الفئران

\author{
شيماء حسن أحمد نجم
}

مستوي FT3, FT4 وارتفاع في مستوي TSH. أدى العلاج عن طريق الفم بكلا من زيت فول الصويا، زيت جوز الهند

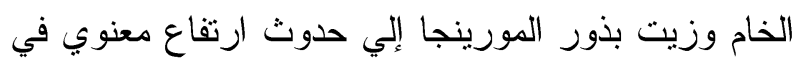

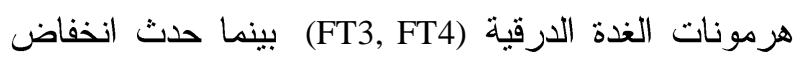
معنوي في مستوي TSH مقارنة بالمجموعة الضابطة

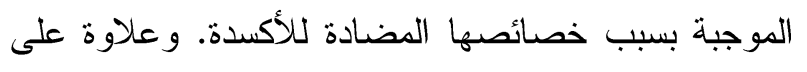
ذلك، فإن مستوىMDA انخفض بشكل ملحوظ وزيادة

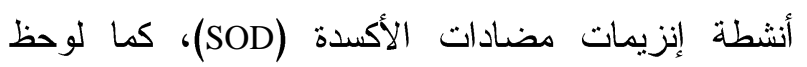

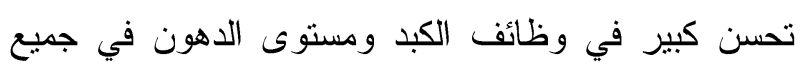
المجموعات المعالجة مقارنة بالمجموعة الضابطة الموجبة.

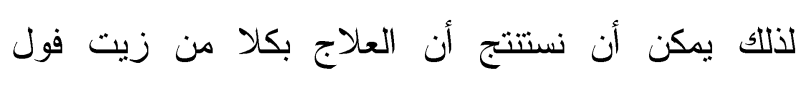

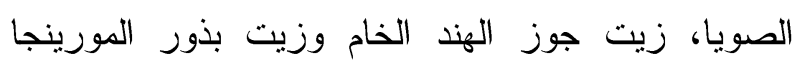
يحسن وظيفة الغدة الدرقية عن طريق تحسين هرمونات

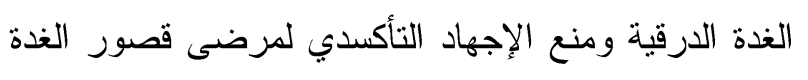

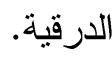

تهدف هذه الدراسة الي معرفة التأثير المحتمل لزيوت فول الصويا وجوز الهند البكر وبذور المورينجا أوليفيرا لمدة ^ اسابيع ضد مادة البروبيل ثيور اسيل (PTU) المسبية

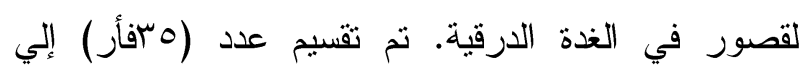
مجمو عتين رئيسيتين: الدجموعة الرئيسية الأولي (V فئران) تتغذي علي الغذاء الاساسي فقط (مجمو عة ضابطة سالبة)،

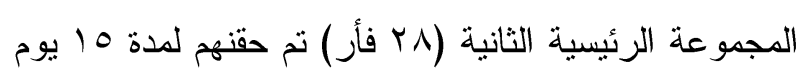

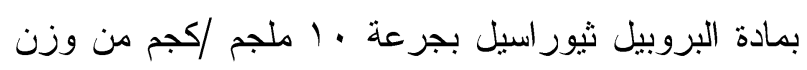

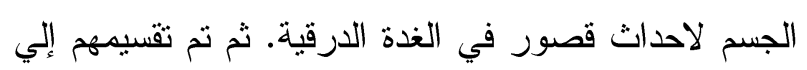

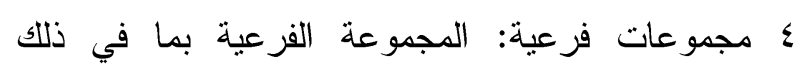
المجموعة الضابطة الموجبة التي تتخذى على النى النظام الغذائي الأساسي، وعولجت المجموعة الفرعية الثانية

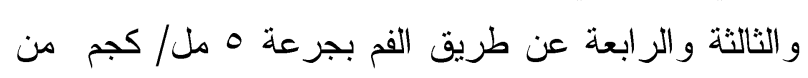

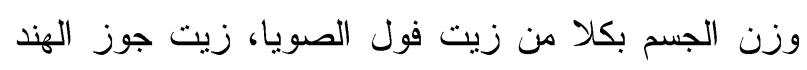
الخام وزيت بذور المورينجا، على التوالي. تشير النتائج إلي أن الفئران الني تم حقنهم بمادة البروبيل ثيور اسيل لديها

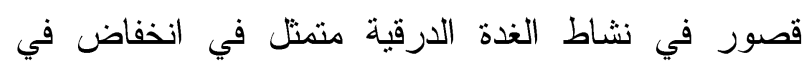

